\title{
Działalność bibliotekarska i bibliofilska profesora Kazimierza Kaczmarczyka (1878-1966), dyrektora Archiwum Państwowego w Poznaniu
}

Streszczenie. Artykuł przedstawia działalność zasłużonego archiwisty i historyka, długoletniego dyrektora Archiwum Państwowego w Poznaniu, prof. dra Kazimierza Kaczmarczyka (1878-1966) w Poznańsko-Pomorskim Kole Związku Bibliotekarzy Polskich, w Związku Bibliotekarzy Polskich Koło Poznańskie, Związku Bibliotekarzy i Archiwistów Polskich Koło Poznańskie oraz w Stowarzyszeniu Bibliotekarzy Polskich Okręg Poznański do roku 1939 oraz w latach 1945-1966. Wspomniano także o udziale Kaczmarczyka w pracach poznańskiego Towarzystwa Bibliofilów Polskich w latach 1924-1939. W artykule omówiono jego księgozbiór oraz starania o sprzedanie książek Wydziałowi Humanistycznemu Uniwersytetu Marii Curie-Skłodowskiej w Lublinie, a następnie Bibliotece Katolickiego Uniwersytetu Lubelskiego.

SŁowA KLUCzowe: archiwum, bibliotekoznawstwo, bibliofilstwo, Stowarzyszenie Bibliotekarzy Polskich.

3 grudnia 2010 roku w gmachu Archiwum Państwowego w Poznaniu, dzięki inicjatywie poznańskiego oddziału Stowarzyszenia Archiwistów Polskich, odbyła się podniosła uroczystość. Sala konferencyjna archiwum została nazwana imieniem profesora Kazimierza Kaczmarczyka, natomiast czytelnia - imieniem profesora Stanisława Nawrockiego. Aktu odsłonięcia tablic pamiątkowych dokonali członkowie rodzin byłych dyrektorów Archiwum Państwowego w Poznaniu.

Uroczystość ta była częścią konferencji Działalność naukowa i zawodowa Prof. Kazimierza Kaczmarczyka i Prof. Stanisława Nawrockiego, na której otwarto także wystawę okolicznościową, a autor niniejszego artykułu wygłosił dwa referaty: jeden - omawiający działalność zawodową i naukową Kazimierza Kaczmarczyka, drugi - przedstawiający 
jego spuściznę, przechowywaną w PAN Archiwum w Warszawie Oddział w Poznaniu.

Nazwanie jednej z sal Archiwum Państwowego w Poznaniu imieniem Kaczmarczyka, a także wystawa, na której zaprezentowano materiały i dokumenty związane z długoletnim dyrektorem poznańskiego archiwum, oraz wygłoszone referaty stanowiły uhonorowanie działalności archiwalnej, naukowej i społecznej jednego z najbardziej zasłużonych archiwistów polskich.

Na temat Kaczmarczyka ukazało się sporo artykułów i opracowań. Większość autorów koncentrowała się na charakterystyce jego działalności zawodowej i naukowej, wybiórczo tylko wspominając udział w towarzystwach naukowych, kulturalnych i społecznych ${ }^{1}$. Niniejszy artykuł jest pierwszą próbą przedstawienia aktywności stowarzyszeniowej byłego dyrektora Archiwum Państwowego w Poznaniu: w oddziale poznańskim Stowarzyszenia Bibliotekarzy Polskich (SBP) do września 1939 roku i w latach 1945-1966 oraz w Towarzystwie Bibliofilów Polskich w latach 1924-1939.

Stowarzyszenie Bibliotekarzy Polskich w ciągu długoletniej działalności kilkakrotnie zmieniało nazwę: w latach 1917-1945 istniało pod nazwą Związek Bibliotekarzy Polskich (ZBP), w 1946 roku zmieniono ją na Związek Bibliotekarzy i Archiwistów Polskich (ZBiAP), a w 1953 roku na Stowarzyszenie Bibliotekarzy Polskich ${ }^{2}$. Zmiany nastąpiły także w oddziale poznańskim SBP, do którego należał Kaczmarczyk. W latach 1920-1928 istniało Koło Poznańskie Związku Bibliotekarzy Polskich, od roku 1928 do września 1939 roku Poznańsko-Pomorskie Koło Związku Bibliotekarzy Polskich, w latach 1945-1946 Związek Bibliotekarzy Polskich Koło Poznańskie, w latach 1946-1953 Związek Bibliotekarzy i Archiwistów Polskich Koło Poznańskie, a od 1953 roku Stowarzyszenie Bibliotekarzy Polskich Okręg Poznański.

Kaczmarczyk posiadał pokaźną bibliotekę prywatną liczącą kilka tysięcy tomów, którą gromadził niemal przez całe życie. Losy tego księgozbioru także przedstawiono w niniejszym opracowaniu.

1 Zob.: I. Radtke, Kazimierz Kaczmarczyk, w: Stownik biograficzny archiwistów polskich, t. 1: 1918-1984, Warszawa-Łódź 1988, s. 93-95; C. Skopowski, Kazimierz Kaczmarczyk 3 II-6 IV 1966, "Archeion” 1967, t. 47, s. 277-280; idem, Kazimierz Kaczmarczyk 1878-1966, w: Życiorysy polskich archiwistów poznańskich i skład osobowy z dnia 8 III 1969 roku, Poznań 1969, s. 21-27; J. Matysiak, Kazimierz Kaczmarczyk (1878-1966) Archiwista $i$ historyk [praca doktorska, maszynopis], Poznań 2010.

2 Zob. Stowarzyszenie Bibliotekarzy Polskich, w: Encyklopedia wiedzy o ksiażce, Wrocław-Warszawa-Kraków 1971, s. 2242; J. Baumgart, Stowarzyszenie Bibliotekarzy Polskich, w: Słownik polskich towarzystw naukowych, t. 1, red. L. Łoś, Wrocław-WarszawaKraków-Gdańsk 1978, s. 169. 
Il. 1. Kazimierz Kaczmarczyk

Źródło: PAN Archiwum, Materiały Kazimierza Kaczmarczyka (1878-1966), sygn. P. III-35.

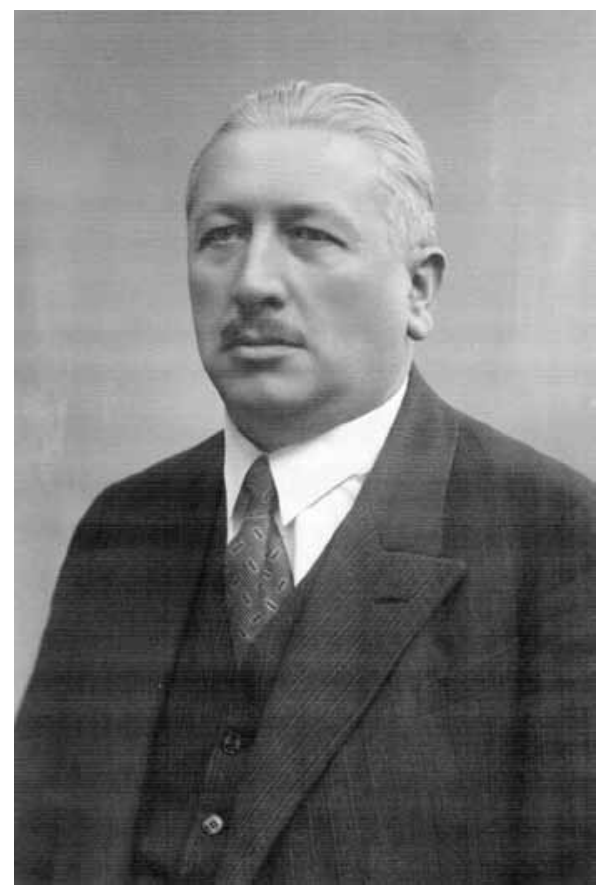

W rozprawie wykorzystałem przede wszystkim dokumenty i materiały przechowywane w PAN Archiwum w Warszawie Oddział w Poznaniu, w spuściźnie Kazimierza Kaczmarczyka³, materiały przechowywane w archiwum Biblioteki Uniwersyteckiej w Poznaniu oraz publikacje i artykuły poświęcone działalności Okręgu Poznańskiego SBP.

Kazimierz Kaczmarczyk urodził się 3 lutego 1878 roku w Wiśniczu Starym w powiecie bocheńskim. Rodzice, Jakub i Marianna, posiadali tylko pół morgi ziemi wniesione w wianie przez matkę. Jakub Kaczmarczyk, nie będąc w stanie utrzymać wielodzietnej rodziny z gospodarstwa,

${ }^{3}$ Polska Akademia Nauk Archiwum w Warszawie Oddział w Poznaniu (dalej: PAN Archiwum), Materiały Kazimierza Kaczmarczyka (sygn. P III-35), jednostki archiwalne (dalej: j.a.) 229, Poznańsko-Pomorskie Koło Związku Bibliotekarzy Polskich; j.a. 230, Związek Bibliotekarzy Polskich Koło Poznańskie; j.a. 231, Związek Bibliotekarzy i Archiwistów Polskich Koło Poznańskie; j.a. 232, Stowarzyszenie Bibliotekarzy Polskich Okręg Poznański. Oprócz dokumentów związanych z działalnością Kaczmarczyka, w jego spuściźnie znajdują się także inne materiały dotyczące prac Okręgu Poznańskiego SBP: zaproszenia, zawiadomienia, sprawozdania, regulaminy, projekty statutów i statuty (często z uwagami i komentarzami Kaczmarczyka), okólniki, listy członków, notatki, artykuły i wycinki prasowe, korespondencja z lat 1938-1957. Wykorzystano także korespondencję wpływającą do Kaczmarczyka oraz kopie pism wychodzących. 
zatrudnił się przy budowie linii kolejowej Chabówka-Nowy Sącz. Następnie przeniósł się na Śląsk Cieszyński, gdzie pracował jako górnik w kopalni węgla w Karwinie. Za zarobione pieniądze dokupił jeszcze dwie morgi gruntu'.

Jak wspominał Kazimierz Kaczmarczyk, ojciec „był we wsi lubiany i poważany z powodu uczynności wielkiej wobec sąsiadów i udzielania im chętnie pomocy. Był też wielce gościnnym dla ubogich i podróżnych, a dom [...] [ich - J.M.] ubogi wyglądał jak karczma zajezdna, był bowiem na rozstaju dróg do sąsiednich wsi" ${ }^{5}$.

Kazimierz pierwsze nauki pobierał $\mathrm{w}$ szkole ludowej $\mathrm{w}$ rodzinnej wsi, a następnie w szkole w sąsiednim Wiśniczu Nowym. W roku szkolnym 1891/1892 rozpoczął naukę w gimnazjum w Bochni. Ze względu na skromne warunki materialne rodziców dorabiał sobie korepetycjami. Atmosfera szkolna sprzyjała tworzeniu tajnych kółek samokształceniowych i nielegalnych stowarzyszeń uczniowskich. W czerwcu 1894 roku założono nielegalne kółko samokształceniowe młodzieży „Przebudzeni" ${ }^{\prime \prime}$, a Kaczmarczyk został jego członkiem wiosną 1895 roku. Zaprzestanie działalności organizacji nastąpiło z końcem maja lub w początkach czerwca 1896 roku7. Hasła i poglądy „Przebudzonych” były bliskie programowi politycznemu polskiego ruchu ludowego. Kazimierz, jak inni członkowie organizacji, prenumerował „Przyjaciela Ludu” - czołowy organ prasowy ludowców ${ }^{8}$. Dyrekcja szkoły zabroniła uczniom czytania

${ }^{4}$ Ibidem, j.a. 321, k. 71.

${ }^{5}$ Ibidem, j.a. 260, k. 29. Fragment przemówienia Kaczmarczyka podczas uroczystego pożegnania w związku z jego przejściem na emeryturę, wygłoszonego w Archiwum Państwowym w Poznaniu 30 kwietnia 1953 roku.

${ }^{6}$ Celem stowarzyszenia było wyrobienie charakterów, samokształcenie, zwłaszcza w zakresie historii i literatury polskiej ponad normę przewidzianą w gimnazjum. Członkowie organizacji uprawiali również gimnastykę, uczyli się szermierki i brali udział w wycieczkach krajoznawczych oraz w uroczystościach patriotycznych. Organizacja miała krzewić ideały moralne i narodowe wśród młodzieży rzemieślniczej i wiejskiej.

${ }^{7}$ Pierwotnie planowano zawiesić działalność na okres wakacji, jednak z powodu wyjazdu głównych organizatorów po zdanej maturze oraz groźby doniesienia o organizacji władzom szkolnym przez jednego z uczniów, który nie został wtajemniczony, stowarzyszenie rozwiązano. Zob. PAN Archiwum, Materiały Kazimierza Kaczmarczyka, j.a. 253, k. 13-14.

8 „Przyjaciel Ludu”, pierwsze polskie polityczne pismo ludowe. Ukazywało się we Lwowie w latach 1889-1902, w Krakowie w latach 1903-1914 i 1919-1933 oraz w Warszawie w latach 1946-1947. Początkowo dwutygodnik, od 1900 roku tygodnik. Od 1895 roku organ SL (potem PSL), po rozłamie w stronnictwie (1913) - organ PSL-Lewicy. Założycielami pisma i jego redaktorami byli czołowi działacze ruchu 
tego czasopisma; konsekwencje złamania tego zakazu były dla Kaczmarczyka opłakane. Decyzją Rady Szkolnej został usunięty z gimnazjum bocheńskiego ${ }^{9}$. Po relegowaniu przeniósł się do gimnazjum w podkrakowskim Podgórzu (obecnie dzielnica Krakowa). Tam też w 1899 roku złożył egzamin dojrzałości.

W 1900 roku rozpoczął studia na Wydziale Filozoficznym Uniwersytetu Jagiellońskiego w Krakowie, a rok później pracę w Archiwum Aktów Dawnych miasta Krakowa. W lipcu 1909 roku uzyskał stopień doktora filozofii na podstawie dysertacji Ciężary ludności wiejskiej i miejskiej na prawie niemieckim $w$ Polsce XIII i XIV $w$. Tytuł profesora nadzwyczajnego otrzymał w lipcu 1957 roku.

W 1919 roku pracował w Archiwum Skarbowym w Warszawie. W 1920 roku przeniósł się do Poznania, gdzie pracował jako wicedyrektor, a od 1925 roku jako dyrektor Archiwum Państwowego w Poznaniu, którym kierował 28 lat, z przerwą w latach II wojny światowej.

Kazimierz Kaczmarczyk brał udział w organizacji państwowej służby archiwalnej, w reorganizacji i tworzeniu archiwów państwowych w Łodzi i Toruniu, uczestniczył także w obradach Rady Archiwalnej, w pracach Komisji Kwalifikacyjnej zajmującej się naborem i sprawdzaniem kwalifikacji osób ubiegających się o stanowiska archiwalne oraz w organizacji szkolnictwa archiwalnego ${ }^{10}$.

Poza pracą zawodową aktywnie uczestniczył w działalności licznych towarzystw naukowych i społecznych, w tym także związanych z bibliotekarstwem i bibliofilstwem ${ }^{11}$. Od 1920 roku działało Koło Poznańskie ZBP, założone przez pierwszego dyrektora biblioteki Uniwersytetu Poznańskiego,

ludowego w Galicji - do 1902 roku Bolesław Wysłouch, od 1902 roku Jan Stapiński. Pismo odegrało ogromną rolę w budzeniu świadomości politycznej chłopów. Do 1911 roku było trybuną radykalnego nurtu ruchu ludowego. Dużo miejsca poświęcało tematyce historycznej i oświatowej. Do współpracowników należeli m.in.: Maria Wysłouchowa, Maciej Szarek, Jakub Bojko, Wojciech Zawada, Dominik Piękoś. Zob. Prasa polska 1864-1918, red. J. Łojek, Warszawa 1976, s. 129, 143, 153 i n.; K. Dunin-Wąsowicz, "Przyjaciel Ludu”, w: Literatura polska. Przewodnik encyklopedyczny, t. 2, red. J. Krzyżanowski, Warszawa 1985, s. 257.

9 PAN Archiwum, Materiały Kazimierza Kaczmarczyka, j.a. 253, k. 9.

10 Oprócz organizowania państwowej służby archiwalnej Kaczmarczyk uczestniczył $\mathrm{w}$ rokowaniach archiwalnych polsko-niemieckich oraz $\mathrm{w}$ rokowaniach archiwalnych polsko-austriackich. Po podpisaniu układów o wymianie i zwrocie akt z Niemcami i z Austrią brał udział w pracach Komisji Odbiorczo-Zdawczej do wymiany akt $\mathrm{z}$ Niemcami oraz $\mathrm{w}$ pracach delegacji przejmującej polskie akta $\mathrm{z}$ archiwów austriackich.

${ }^{11}$ Dokładniejsze omówienie działalności Kaczmarczyka w towarzystwach naukowych i społecznych w: J. Matysiak, Kazimierz Kaczmarczyk..., s. 181-211. 
dra Edwarda Kuntze (1880-1950), przemianowane następnie w 1928 roku na Poznańsko-Pomorskie Koło ZBP ${ }^{12}$. Nie wiadomo, kiedy Kaczmarczyk został członkiem koła. Najprawdopodobniej stało się to $w$ latach 20. XX wieku. O tej działalności zachowały się w jego spuściźnie szczątkowe materiały: m.in. zaproszenie na zwyczajne miesięczne zebranie w Bibliotece Uniwersyteckiej, wyznaczone na 31 stycznia 1939 roku, oraz Sprawozdanie z działalności Koła Poznańsko-Pomorskiego Związku Bibliotekarzy Polskich za czas od 1 stycznia do 31 grudnia 1938. W tym okresie funkcję przewodniczącego koła pełnił dr Andrzej Wojtkowski (1891-1975), zastępcą przewodniczącego była prof. dr Ludwika Dobrzyńska-Rybicka (1868-1958), sekretarzem mgr Jan Baumgart (1904-1989), skarbnikiem Maria Golska, a gospodarzem dr Bożenna Szulc-Golska (1885-1966). Kazimierz Kaczmarczyk natomiast, obok dra Jerzego Kollera i dr Marii Rymarkiewicz (1887-1967), był członkiem Komisji Rewizyjnej koła ${ }^{13}$.

Według spisu z 1 lutego 1939 roku Poznańsko-Pomorskie Koło ZBP liczyło 66 osób, przeważnie zamieszkałych i pracujących w Poznaniu, ale członkami byli także bibliotekarze z Bydgoszczy, Gniezna, Kalisza, Kórnika, Pelplina, Torunia, Włocławka. Do koła należeli między innymi: Ludwika Dobrzyńska-Rybicka, bibliotekarz, filozof; prof. dr Zdzisław Grot (1903-1984), historyk; ks. dr Józef Nowacki (1893-1964), historyk, archiwista; prof. dr Maria Wojciechowska (1902-1990), historyk ${ }^{14}$.

Poza udziałem w pracach Poznańsko-Pomorskiego Koła ZBP Kaczmarczyk uczestniczył także w działalności Towarzystwa Bibliofilów Polskich, wchodził w skład jego Komisji Rewizyjnej ${ }^{15}$. Inicjatorem utworzenia towarzystwa był dyrektor Archiwum Archidiecezjalnego w Poznaniu ks. Edmund K. Majkowski (1892-1951). 15 lutego 1923 roku w Bibliotece

12 PAN Archiwum, Materiały Kazimierza Kaczmarczyka, j.a. 229, Sprawozdanie z działalności Koła Poznańsko-Pomorskiego Związku Bibliotekarzy Polskich za czas od 1 stycznia do 31 grudnia 1938 r.; 29 marca 1938 roku przewodniczący koła dr Andrzej Wojtkowski wygłosił referat Działalność Koła Poznańsko-Pomorskiego Z.B.P. w latach 1928-1938.

13 Ibidem, j.a. 229, Poznańsko-Pomorskie Koło Związku Bibliotekarzy Polskich. Sprawozdanie z działalności Koła Poznańsko-Pomorskiego Związku Bibliotekarzy Polskich..., k. 5.

14 Zob. ibidem, j.a. 229, Spis członków Koła Poznańsko-Pomorskiego Związku Bibliotekarzy Polskich. Stan z dnia 1 II 1939, k. 8. Jako swoistą ciekawostkę można odnotować, że członkiem koła był także dr Kurt Lück (1900-1942), niemiecki historyk, etnograf, jedna z czołowych postaci części mniejszości niemieckiej mieszkającej w Poznaniu, która otwarcie sympatyzowała z ruchem narodowosocjalistycznym i we wrześniu 1939 roku wystąpiła aktywnie przeciwko Polsce.

15 U naszych bibliofilów, „Kurier Poznański”, nr 165 z 9 kwietnia 1933, s. 8. 
Uniwersyteckiej w Poznaniu odbyło się zebranie założycielskie towarzystwa. W skład pierwszego Zarządu weszli: dr Edward Kuntze jako prezes, ks. Edmund Majkowski, wiceprezes, Jan W. Kuglin (1892-1972), sekretarz, dr Bożenna Szulc-Golska, członek Zarządu, oraz inż. dypl. Bronisław Przybylski, skarbnik. Do zadań towarzystwa, trzeciej po Warszawie i Krakowie organizacji bibliofilskiej, należało szerzenie kultu pięknej i dobrej książki przez wygłaszanie odczytów, urządzanie wystaw, udział w krajowych i zagranicznych zjazdach, a także wydawanie druków bibliofilskich ${ }^{16}$. W latach 30., z powodu ogólnego kryzysu gospodarczego, prace towarzystwa uległy znacznemu osłabieniu, a wybuch II wojny światowej przerwał całkowicie działalność bibliofilską.

W spuściźnie Kaczmarczyka przechowywanej w poznańskim oddziale PAN Archiwum nie zachowały się, niestety, materiały dotyczące jego działalności w towarzystwie. Nie wiemy, kiedy został jego członkiem. Z dużym prawdopodobieństwem należy przyjać, że stało się to niedługo po utworzeniu organizacji.

Kazimierz Kaczmarczyk, pełniąc obowiązki dyrektora Archiwum Państwowego w Poznaniu, doceniał i rozumiał potrzebę posiadania odpowiedniego księgozbioru, niezbędnego w pracy archiwalnej. Po przejęciu archiwum z rąk niemieckich bezpośrednim opiekunem biblioteki archiwalnej od 1920 roku był dr Andrzej Wojtkowski. Przez trzy lata kierował biblioteką podręczna, liczącą wówczas około 12000 tomów, sporządził katalog kartkowy rozpraw zawartych w pismach periodycznych znajdujących się w archiwum. Dzięki zabiegom Kaczmarczyka Ministerstwo byłej Dzielnicy Pruskiej przyznało odpowiednie środki finansowe, co umożliwiło zakup wielu opracowań polskich. Zasób biblioteczny powiększał się także dzięki licznym darom od osób prywatnych i instytucji ${ }^{17}$.

${ }^{16}$ J. Kurjata, B. Szornel-Dąbrowska, Towarzystwo Bibliofilów Polskich w Poznaniu, w: Słownik polskich towarzystw naukowych, t. 2, cz. 2, Warszawa 1994, s. 437.

${ }^{17}$ Między innymi w 1922 roku ks. prof. Stanisław Kozierowski (1874-1949) przekazał w darze dla biblioteki archiwalnej swoją rozprawę Pierwotne osiedlenie pojezierza Gopła. Zob. PAN Archiwum, Materiały Stanisława Kozierowskiego (sygn. P III-15), Pismo Archiwum Państwowego w Poznaniu L. dz. 512 z dnia 2 września 1922 roku z podziękowaniem dla ks. Kozierowskiego za przekazaną pracę, j.a. 326, k. 16. Nie zawsze starania o powiększenie zasobu biblioteki archiwalnej kończyły się sukcesem. Tak było z księgozbiorem Historische Gesellschaft Posen. Sprawa jego umieszczenia była tematem posiedzenia Rady Archiwalnej działającej w Urzędzie Głównym Archiwów Państwowych b. Dzielnicy Pruskiej, które odbyło się 21 grudnia 1920 roku w Bibliotece Uniwersyteckiej w Poznaniu. Ostatecznie księgozbiór trafił do Muzeum Wojskowego w Poznaniu. Zob. ibidem, j.a. 326, k. 15, Pismo Urzędu Głównego Archiwów Państwowych b. Dzielnicy Pruskiej L. dz. 126 z dnia 15 grudnia 1920 roku do ks. Kozierowskiego; Archiwum Państwowe w Poznaniu, Spuścizna Józefa 
Po wybuchu wojny dyrektor zarządził ewakuację części akt Archiwum Państwowego w Poznaniu w głąb kraju. Po powrocie z wojennej tułaczki, pod koniec września 1939 roku, został aresztowany przez Gestapo. Po kilku dniach zwolniony, w listopadzie został osadzony (wraz z synem i synową) w niemieckim obozie przejściowym na Głównej (Lager Glowna) w Poznaniu i wywieziony do Generalnego Gubernatorstwa. Od grudnia 1939 do lipca 1940 roku porządkował archiwum oo. Paulinów na Jasnej Górze w Częstochowie.

W sierpniu 1940 roku rozpoczął pracę w Archiwum Państwowym w Krakowie, gdzie pracował z przerwami do marca 1945 roku. Zajmował się porządkowaniem archiwów instytucji, m.in. Uniwersytetu Jagiellońskiego, oraz zgromadzeń zakonnych. Latem i jesienią 1944 roku w klasztorze oo. Paulinów na Jasnej Górze uczestniczył w gromadzeniu i zabezpieczaniu archiwaliów wywiezionych z Warszawy, nad którymi następnie sprawował nadzór do marca 1945 roku. Jednocześnie wykładał nauki pomocnicze historii (archiwistyka, dyplomatyka, paleografia) na tajnym Uniwersytecie Ziem Zachodnich w Częstochowie.

Po powrocie w maju 1945 roku do Poznania Kaczmarczyk włączył się ponownie w działalność organizacyjną Koła Poznańskiego ZBP. Trzeba podkreślić, że mimo nawału pracy przy odbudowie poznańskiego archiwum (które po placówkach warszawskich było najbardziej zniszczone w kraju) i licznych problemach natury organizacyjnej, lokalowej i personalnej znajdował czas na udział $\mathrm{w}$ posiedzeniach poznańskiego oddziału. 16 października 1945 roku uczestniczył w pierwszym powojennym Walnym Zebraniu Koła. Na przewodniczącego został wybrany wówczas prof. dr Aleksander Birkenmajer (1890-1967), dyrektor Biblioteki Uniwersyteckiej, sekretarzem został dr Jan Baumgart ${ }^{18}$.

Niecały miesiąc później, 6 listopada, na zorganizowanej uroczystości ku czci zmarłych członków Kaczmarczyk po raz pierwszy wystąpił publicznie. Wygłosił wspomnienie pośmiertne o historyku i archiwiście, pracowniku Archiwum Państwowego w Poznaniu - drze Feliksie Pohoreckim (1890-1945) ${ }^{19} .12$ marca 1946 roku na kolejnym zebraniu koła, w Czytelni Czasopism Biblioteki Uniwersyteckiej, wygłosił referat Katalog dzieł fikcyjnych z czasów insurekcji Kościuszkowskiej (il. 2).

Paczkowskiego, sygn. 438. Pismo Kaczmarczyka do Paczkowskiego z dnia 27 grudnia 1920 roku. Na temat biblioteki Archiwum Państwowego w Poznaniu zob. też F. Pohorecki, Biblioteka Archiwum Państwowego 1869-1929, w: Biblioteki wielkopolskie i pomorskie, red. S. Wierczyński, Poznań 1929, s. 75, 79.

${ }^{18}$ K. Michałowski, Biblioteki poznańskie przed pót wiekiem, „Biblioteka” 1997, nr 1, s. 138.

${ }^{19}$ PAN Archiwum, Materiały Kazimierza Kaczmarczyka, j.a. 230, k. 1-3. 
Il. 2. Okólnik wydany przez ZBP Koło Poznańskie z dnia 7 marca 1946 roku

Źródło: PAN Archiwum, Materiały Kazimierza Kaczmarczyka (1878-1966), sygn. P. III-35.

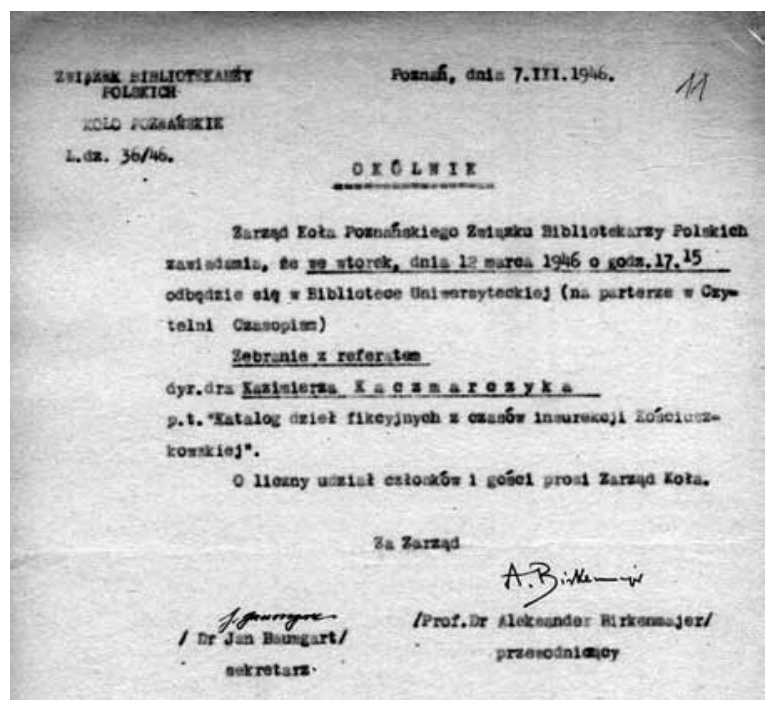

Angażując się w działalność Poznańskiego Koła ZBP i pracując usilnie nad odtworzeniem zasobu archiwalnego, Kaczmarczyk nie zapominał o zniszczonej w czasie walk o Poznań, zimą 1945 roku, bibliotece Archiwum Państwowego, liczącej przed wybuchem wojny około 30000 tomów. „Nasza biblioteka archiwalna, niestety, w całości spłonęła podpalona przez Niemców, jesteśmy pozbawieni zupełnie książek, co jest dla nas prawdziwą katastrofa, tym większa, że był to piękny zbiór dzieł źródłowych i opracowań do Wielkopolski, a dziś nie jesteśmy w stanie nowej biblioteki odtworzyć" 20 - pisał w liście do ks. prof. Stanisława Kozierowskiego w listopadzie 1945 roku.

Ksiądz Kozierowski doskonale rozumiał sytuację, w jakiej znalazło się Archiwum Państwowe w Poznaniu, i w lutym 1946 roku ofiarował bibliotece archiwalnej szesnaście książek ze swojego księgozbioru. W 1949 roku, po śmierci księdza, biblioteka przejęła w spadku 6908 tomów ${ }^{21}$. Udało się także pozyskać kilka tysięcy książek, przeważnie poniemieckich, pochodzących z różnych bibliotek poniemieckich: publicznych i prywatnych ${ }^{22}$.

${ }^{20}$ PAN Archiwum, Materiały Stanisława Kozierowskiego, list Kaczmarczyka do Kozierowskiego z 10 listopada 1945 roku, j.a. 335, k. 11-12.

${ }^{21}$ Ibidem, j.a. 326, k. 33, pismo Dyrekcji Archiwum Państwowego w Poznaniu L. dz. 246/2/46 z dnia 4 kwietnia 1946 roku potwierdzające odbiór przekazanych przez ks. Kozierowskiego tomów; M. Bielińska, J. Durko, Sprawozdanie z działalności Wydziału Archiwów Państwowych w latach 1950-1951, „Archeion” 1951, t. 19-20, s. 489.

22 A. Rybarski, Działalność Archiwów Państwowych w latach 1945-1947, „Archeion” 1948 , t. 18 , s. 252. 


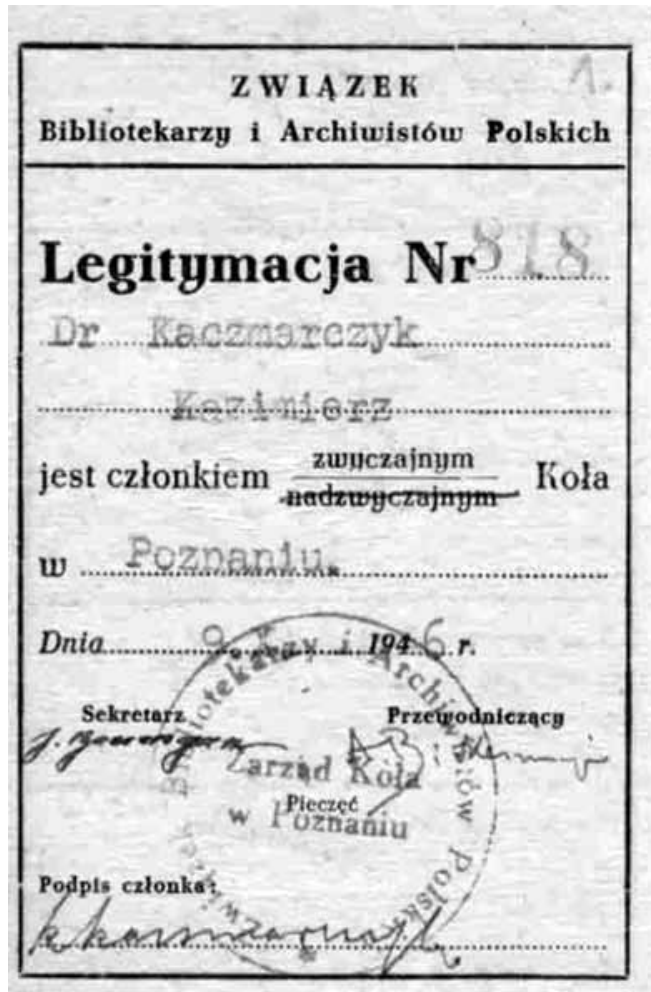

Il. 3. Legitymacja członkowska ZBiAP Źródło: PAN Archiwum, Materiały Kazimierza Kaczmarczyka (1878-1966), sygn. P. III-35.

W 1946 roku Związek Zawodowy Bibliotekarzy Polskich został przemianowany na Związek Bibliotekarzy i Archiwistów Polskich. W wyniku zmian organizacyjnych członkowie związku otrzymali nowe legitymacje. Kazimierz Kaczmarczyk otrzymał legitymację o numerze 818 wystawioną 9 października 1946 roku $^{23}$ (il. 3).

Na zebraniach Koła Poznańskiego ZBiAP nie tylko przedstawiano referaty i sprawozdania poświęcone działalności związku oraz bibliotek polskich i zagranicznych, ale też chętnie słuchano odczytów na temat archiwistyki. 14 grudnia 1946 roku na Zebraniu Referatowym Koła Poznańskiego ZBiAP, które odbyło sie w Bibliotece Uniwersyteckiej, Kaczmarczyk wygłosił odczyt Stan archiwaliów na Zachodzie ${ }^{24}$.

18 stycznia 1947 roku na Walnym Zebraniu Koła Poznańskiego dyrektor Archiwum Państwowego w Poznaniu został wybrany zastępcą przewodniczącego na rok 1947 (przewagą głosów 22 na 24 oddane).

\footnotetext{
${ }^{23}$ PAN Archiwum, Materiały Kazimierza Kaczmarczyka, j.a. 231, k. 1.

${ }^{24}$ Ibidem, j.a. 231, Okólnik Zarządu L. dz. 159/46 z dnia 9 grudnia 1946 roku, k. 11.
} 
Il. 4. Okólnik wydany przez ZBiAP Koło Poznańskie z dnia 20 listopada 1947 roku

Źródło: PAN Archiwum, Materiały Kazimierza Kaczmarczyka (1878-1966), sygn. P. III-35.

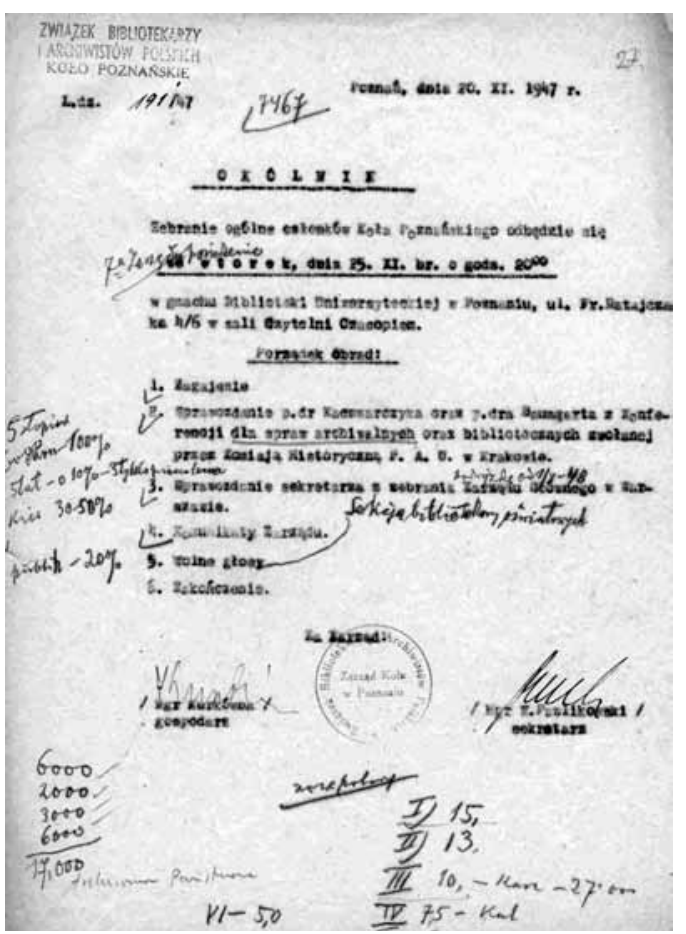

Przewodniczącym koła został ponownie prof. dr Aleksander Birkenmajer, sekretarzem mgr Witold Pawlikowski (1910-1985), skarbnikiem Maria Golska, a gospodarzem mgr Halina Kurkówna (1908-1995) ${ }^{25} .24$ marca 1947 roku Kaczmarczyk, jako zastępca oddziału, przewodniczył Nadzwyczajnemu Walnemu Zebraniu Koła, które odbyło się w sekretariacie Biblioteki Uniwersyteckiej ${ }^{26}$.

Podczas kolejnego zebrania ogólnego członków koła, 25 listopada 1947 roku, wraz z drem Baumgartem przedstawił sprawozdanie z konferencji instytucji i towarzystw naukowych uprawiających badania historyczne, zwołanej przez Komisję Historyczną Polskiej Akademii Umiejętności w Krakowie 26 i 27 października 1947 roku$^{27}$ (il. 4).

${ }^{25}$ Ibidem, j.a. 231, Pismo Zarządu L. dz. 22/47 z dnia 20 lutego 1947 roku, k. 12; Archiwum Biblioteki Uniwersyteckiej w Poznaniu, teka: BU Sekretariat, organizacje polityczne, młodzieżowe i społeczne 1945-1955, sygn. 935, k. 14.

${ }^{26}$ PAN Archiwum, Materiały Kazimierza Kaczmarczyka, j.a. 231, Okólnik Zarządu L. dz. $42 / 47$ z dnia 17 marca 1947 roku, notatka Kaczmarczyka na okólniku, k. 20.

${ }^{27}$ Ibidem, j.a. 231, Okólnik Zarządu L. dz. 191/47 z dnia 20 listopada 1947 roku; ibidem, j.a. 210, Konferencja Instytucji i Towarzystw Naukowych Uprawiających Badania Historyczne w Krakowie 26-27 października 1947 roku. 
Niecały miesiąc później, 21 grudnia 1947 roku, podczas wieczorku opłatkowego, Kaczmarczyk w imieniu członków oddziału pożegnał odchodzącego do Biblioteki Uniwersytetu Jagiellońskiego kolegę - dra Baumgarta ${ }^{28}$.

Na dzień 1 stycznia 1948 roku Koło Poznańskie ZBiAP liczyło 83 członków. Do koła należeli przeważnie pracownicy archiwów państwowych, bibliotek: instytucji, uczelni wyższych, publicznych, z Poznania i Wielkopolski ${ }^{29}$. Liczne grono osób stanowili przedwojenni członkowie Poznańsko-Pomorskiego Koła ZBP.

13 marca 1948 roku, w trakcie kolejnego Walnego Zjazdu Koła, Kaczmarczyk został ponownie wybrany na zastępcę przewodniczącego. Przewodniczącym została dr Zofia Kawecka, a sekretarzem mgr Maria Zwolińska. Dyrektora poznańskiego archiwum wytypowano także, razem z dr Kawecka, jako delegata na zebranie delegatów ZBiAP ${ }^{30}$. Ponowny wybór na zastępcę przewodniczącego świadczył o dużym zaufaniu członków Koła Poznańskiego. Bibliotekarze poznańscy docenili w ten sposób działalność organizacyjną Kaczmarczyka.

28 Tekst przemówienia Kaczmarczyka wygłoszonego podczas pożegnania dra Jana Baumgarta, odchodzącego do Biblioteki Jagiellońskiej w Krakowie, w imieniu Poznańskiego Koła Związku Bibliotekarzy i Archiwistów Polskich 21 grudnia 1947 roku: „Wielce Szan[owny], a dla mnie i wielu tu obecnych kochany Panie Doktorze! Byłeś współzałożycielem naszego Oddziału, a jako długoletni sekretarz i delegat do Zarządu Głównego byłeś jego prawdziwą kolumną na której barkach spoczywały wszystkie sprawy Oddziału. Twoją osoba, pełną zapału, energii i inicjatywy stał Oddział przez długie lata, organizowałeś referaty naukowe i posiedzenia nasze, zawsze ochoczy do pracy, toteż imieniem Oddziału Poznańskiego wyrażam Ci naszą wdzięczność i zapewnienie, że o Twej mozolnej dla nas pracy nie zapomnimy i we wdzięcznej przechowamy pamięci. Przechodzisz do Krakowa, na stanowisko zaszczytne w najstarszej, bo przeszło 5-cio wiekową tradycją owianej biblioteki, najbogatszej dziś w Polsce po katastrofie wojennej. Żegnamy Cię z podwójnymi uczuciami żalu i radości. Żalu, że opuszczasz nasze szeregi - radości, że zdobyłeś zaufanie władz przełożonych, że spotkało Cię wielkie wyróżnienie i uznanie, zresztą dobrze zasłużone za Twą umiejętną i pełną poświęcenia pracę. Mimo nieobecności fizycznej w Poznaniu, duch Twój tu zostanie i kontakt dalej utrzymasz z nami, zostawiasz tu nie Tylko dobrą pamięć, ale i ukochanych Sułkowskich, którzy tu wnet będą drukowani. Imieniem Oddziału żegnając Cię składam Ci życzenia, Kochany wicedyrektorze Jagiellonki, owocnej pracy na nowym posterunku, pełnej zadowolenia osobistego i najlepszych wyników w tej pracy dla dobra ogólnego". Ibidem, j.a. 231, k. 29-30. Baumgart w styczniu 1948 roku objął stanowisko zastępcy dyrektora i kierownika Działu Udostępniania Zbiorów Biblioteki Jagiellońskiej w Krakowie.

${ }^{29}$ Ibidem, j.a. 231, Spis członków Koła Poznańskiego ZBiAP - stan z dnia 1 I 1948 roku, k. 33-35.

${ }^{30}$ Ibidem, j.a. 231, Okólnik Zarządu Koła Poznańskiego ZBiAP, L. dz. 35/48 z dnia 5 marca 1948 roku, k. 31, wykaz wybranych osób do Zarządu Koła, k. 32. 
Pod koniec życia, m.in. ze względu na pogarszający się stan zdrowia, Kaczmarczyk nie uczestniczył już tak aktywnie w działalności Okręgu Poznańskiego SBP 31 .

Poza aktywnością w towarzystwach bibliotekarskich i bibliofilskich Kaczmarczyk gromadził na temat książek, bibliotek, bibliotekarzy i wszelkich spraw bibliotecznych całą dostępną literaturę oraz artykuły i wycinki prasowe z prasy poznańskiej, ogólnopolskiej i zagranicznej (przeważnie niemieckiej). W jego spuściźnie, przechowywanej w poznańskim oddziale PAN Archiwum, znajduje się kilkanaście teczek z artykułami i wycinkami prasowymi poświęconymi problemom bibliotekarstwa polskiego i zagranicznego z lat $1895-1965^{32}$.

Na koniec należy wspomnieć także o jego prywatnej bibliotece. Księgozbiór ten gromadził przez cały okres swojej działalności zawodowej i naukowej, kupując oraz otrzymując druki od autorów, przyjaciół, współpracowników lub od instytucji i redakcji. Jego biblioteka liczyła kilka tysięcy książek polskich i obcojęzycznych (przeważnie austriackich, francuskich, niemieckich, rosyjskich) z XIX i pierwszej połowy XX wieku, dotyczących m.in. archiwów (państwowych, prywatnych, kościelnych, klasztornych, polskich i zagranicznych) i archiwistyki, bibliotek (publicznych, prywatnych, kościelnych i klasztornych) i bibliotekarstwa, heraldyki, numizmatyki, księgarstwa, paleografii, sfragistyki, historii Polski, historii wojskowości polskiej, historii Kościoła katolickiego w Polsce, muzeów (państwowych i kościelnych) i muzealnictwa, polityki, biografistyki. W skład księgozbioru wchodziły też liczne inwentarze archiwalne i biblioteczne, katalogi: biblioteczne, czasopism i wydawnictw ciągłych, muzealne, dotyczące wystaw okolicznościowych, przewodniki muzealne, słowniki tematyczne, sprawozdania, roczniki, instrukcje oraz czasopisma tematyczne (archiwalne, biblioteczne, muzealne) polskie i zagraniczne. Uzupełnieniem było kilka tysięcy wycinków z prasy regionalnej (poznańskiej, krakowskiej), ogólnopolskiej i zagranicznej ${ }^{33}$.

Ten bogaty i różnorodny tematycznie księgozbiór świadczył o rozległych zainteresowaniach jego właściciela. Kaczmarczyk nie skupiał się

${ }^{31}$ Ibidem, j.a. 232.

${ }^{32}$ Ibidem, j.a. 100, Biblioteki poznańskie i wielkopolskie; j.a. 101, Biblioteka Jagiellońska w Krakowie; j.a. 102, Biblioteka Narodowa w Warszawie; j.a. 103, Biblioteka Zakładu Narodowego im. Ossolińskich; j.a. 104, Biblioteki polskie, problemy bibliotek i bibliotekarstwa, spotkania z książkami; j.a. 105, Biblioteki polskie za granica; j.a. 106, Biblioteki zagraniczne; j.a. 107, I Zjazd Bibliotekarzy Polskich, Lwów 26-29.05.1928; j.a. 108, Krajowe i międzynarodowe Zjazdy Bibliotekarzy, Targi Książki.

${ }^{33}$ Ibidem, j.a. 292. 
wyłącznie na sprawach archiwalnych, ale zajmował się także innymi szeroko pojętymi naukami pomocniczymi historii.

Pod koniec życia Kaczmarczyk postanowił sprzedać swoją bibliotekę na potrzeby Uniwersytetu Marii Curie-Skłodowskiej w Lublinie. Intencją jego było, aby ten bogaty i różnorodny księgozbiór, pieczołowicie gromadzony przez całe życie, dalej służył nauce i młodemu pokoleniu. Przez doc. dra Tadeusza Mencla (1912-1987) ${ }^{34}$ nawiązał kontakt z ówczesnym dziekanem Wydziału Humanistycznego doc. drem Kazimierzem Myślińskim (1916-1999), który w imieniu Wydziału Humanistycznego Uniwersytetu Marii Curie-Skłodowskiej zwrócił się o potwierdzenie oferty sprzedaży, opis książek oraz o podanie przybliżonej wartości księgozbioru ${ }^{35}$.

Kaczmarczyk przesłał do dra Myślińskiego spis zawierający 3610 pozycji. W odpowiedzi listownej dziekan zaznaczył, że nie jest możliwe zakupienie całego księgozbioru. Każdy z zakładów Wydziału Humanistycznego miał zakupić potrzebną część osobno, na co z kolei nie chciał się zgodzić Kaczmarczyk ${ }^{36}$. Zależało mu, aby księgozbiór sprzedać w całości. Ostatecznie transakcja nie doszła do skutku.

Jeszcze w trakcie negocjacji z dziekanem Myślińskim Kaczmarczyk zaproponował we wrześniu 1960 roku kupno księgozbioru Bibliotece Uniwersyteckiej Katolickiego Uniwersytetu Lubelskiego ${ }^{37}$. Odpowiedź dyrektora biblioteki o. dra Romualda Gustawa (OFM) (1911-1976) była pozytywna $^{38}$. W grudniu 1960 roku księgozbiór wyceniony na 135014 zł brutto staraniem i na koszt biblioteki został przetransportowany z Poznania do Lublina. Po wyłączeniu dubletów biblioteka zakupiła książki za sumę 30123 zł. Dublety przekazano do Księgarni św. Wojciecha

${ }^{34}$ W latach 1947-1956 Tadeusz Mencel był pracownikiem Archiwum Państwowego w Poznaniu.

${ }^{35}$ PAN Archiwum, Materiały Kazimierza Kaczmarczyka, j.a. 279, pismo Dziekana Wydziału Humanistycznego UMCS w Lublinie doc. dra Kazimierza Myślińskiego z dnia 4 stycznia 1960 roku do K. Kaczmarczyka, k. 137.

${ }^{36}$ Ibidem, j.a. 274, kopia pisma K. Kaczmarczyka do K. Myślińskiego z dnia 5 kwietnia 1960 roku, k. 58; ibidem, j.a. 279, pismo K. Myślińskiego do K. Kaczmarczyka z dnia 20 maja 1960 roku, k. 139.

37 Ibidem, j.a. 274, kopia pisma Kaczmarczyka do dyrektora Biblioteki Uniwersyteckiej KUL o. Romualda Gustawa (OFM) z dnia 21 września 1960 roku, k. 31.

${ }^{38}$ Ibidem, j.a. 277, pismo o. Romualda Gustawa do K. Kaczmarczyka w sprawie zakupu książek przez bibliotekę z dnia 7 października 1960 roku, k. 119. Nie był to pierwszy kontakt Kaczmarczyka z biblioteką. W 1956 roku przekazał w darze siedem pozycji ze swojego księgozbioru. Zob. ibidem, j.a. 277, pismo dyrekcji Biblioteki KUL L. dz. A-2/66/56 z dnia 6 listopada 1956 roku do K. Kaczmarczyka z podziękowaniem i potwierdzeniem odbioru przekazanych w darze książek i czasopism, k. 118. 
Il. 5. Ekslibris Kazimierza Kaczmarczyka Źródło: PAN Archiwum, Materiały Kazimierza Kaczmarczyka (1878-1966), sygn. P. III-35.

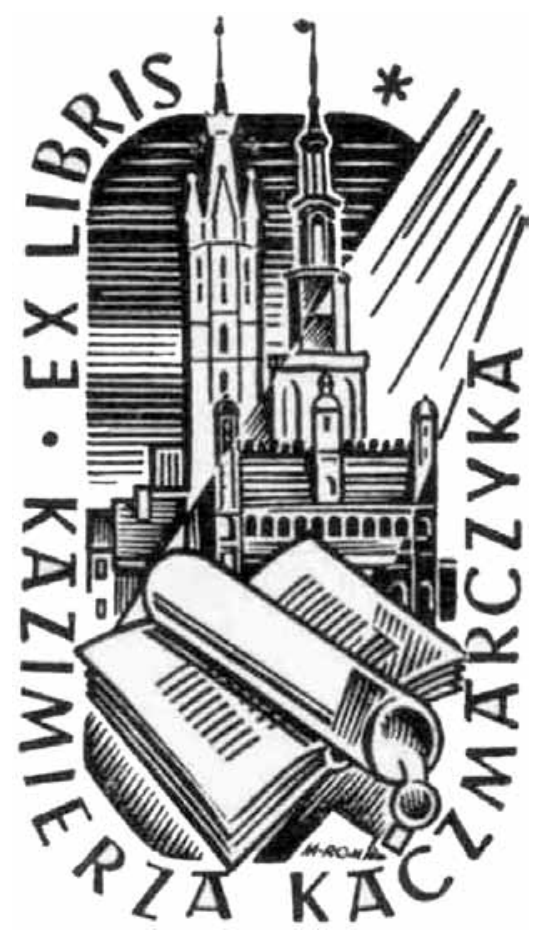

w Lublinie, wyceniając je na sumę 82 128,15 zł. Części księgozbioru, około 380 tytułów, księgarnia nie przyjęła, nie mając nadziei na ich sprzedaż, i książki te zwrócono Kaczmarczykowi ${ }^{39}$.

Zakup książek przez Bibliotekę Uniwersytecką KUL był jednym z elementów planu powiększania zasobu, realizowanego przez dyrektora, m.in. przez nabywanie księgozbiorów prywatnych ${ }^{40}$.

Kilkadziesiąt pozycji z biblioteki prywatnej Kaczmarczyka trafiło razem z jego spuścizną do PAN Archiwum w Warszawie Oddział w Poznaniu.

Książki z jego księgozbioru były zdobione oryginalnym ekslibrisem przedstawiającym wieżę kościoła Mariackiego w Krakowie oraz ratusz w Poznaniu - charakterystyczne budowle miast, z którymi Kaczmarczyk był związany zawodowo, naukowo i rodzinnie (il. 5).

${ }^{39}$ Ibidem, j.a. 277, Sprawozdanie z nabycia księgozbioru od prof. Kazimierza Kaczmarczyka sporządzone przez kierownika Działu Akcesji Biblioteki Uniwersyteckiej z dnia 29 sierpnia 1961 roku, dołączone do pisma o. Romualda Gustawa (OFM) z dnia 5 września 1961 roku, k. 126.

40 Biblioteka zakupiła także księgozbiory: Edmunda Bulandy, ks. bpa Czesława Sokołowskiego, Zygmunta Klukowskiego, ks. Eugeniusza Dąbrowskiego, ks. Ignacego Wierobieja. 
Profesor Kazimierz Kaczmarczyk zmarł 6 kwietnia 1966 roku i został pochowany na Cmentarzu Junikowskim w Poznaniu.

\title{
JAROSŁAW MATYSIAK
}

\section{The library and bibliophilic activity of Prof. Kazimierz Kaczmarczyk (1878-1966), director of the State Archives in Poznań}

\begin{abstract}
Aвstract. This article describes the work of the distinguished archivist and prominent historian Prof. Kazimierz Kaczmarczyk (1878-1966), a long time director of the State Archives in Poznań, in the Poznań-Pomorze Polish Librarians Union, the Poznan branch of the Polish Librarians and Archivists Union and in the Poznan branch of the Polish Librarians Association until 1939 and in the post-war years of 1945-1966. Prof. Kaczmarczyk's participation in the works of the Poznan'-based Association of Polish Bibliophiles between 1924 and 1939 is also briefly mentioned. The article discusses a vast collection of books that belonged to the Professor and the attempts to sell these holdings to the faculty of the Humanities of M. Curie-Skłodowska University in Lublin and later to the library of the Catholic University in Lublin.
\end{abstract}

Key words: archives, library studies, bibliophily, the Polish Librarians Association. 